\title{
EDUCATION, TRANSHUMANISM AND EUGENICS IN SCIENCE FICTION WORKS OF HUXLEY, ASIMOV AND NICCOL
}

\begin{abstract}
Science fiction literature and film are often seen as a mere pastime. However, science fiction literature and film are a critique of the ideas propagated in the time of the author and of the possible outcomes technological advancements might have on society. The goal of this paper is to give a critical overview on the ways the subject of education has been regarded in Aldous Huxley's "Brave New World”(1932), Isaac Asimov's “The Naked Sun”(1957), and Andrew Niccol's film "Gattaca"(1997). Education was often seen as a means of social control, and in the case of afore mentioned authors it is a means by which a dystopian society achieves subjugation of the subjects. The pillars of such educational systems are elimination of free thought, over-reliance on technology and education is often coupled with eugenics and transhumanism. The paper will also discuss the basic ideas behind eugenics and transhumanism as well as the relationship between the eugenic and transhumanist movements.
\end{abstract}

Key words: science fiction, transhumanism, eugenics, dystopia. subjugation.

\section{Introduction}

The paper will discuss education in the works of Huxley, Asimov, Kress and Niccol. These authors belong to the genre of Science fiction which is often omitted and rarely seen as fit as a subject of any serious considerations. Yet, science fiction reveals to the reader the possible outcomes of the advances in technology. In 1964 Asimov gave the following definition of science fiction:

"Science fiction may be defined as that branch ofliterature which deals with the response of human beings toadvances in science and technology. Science fiction is based on the fact of social change. It accepts the fact of change. In a sense, it tries various changes fo rsize; it tries to penetrate the consequences of this change or that; and in the form of a story, it presents the results to the view of the public, a public that needs more and more to have the possibilities of change pointed out to it before it is disastrously overwhelmed by it."(Asimov, 1964 quoted in Goble, 1972, p. 32 )

This definition shows the goal of Asimov's science fiction to point out possible changes that the future may bring. Asimov saw the advancements in technology as inevitable and the public must accept them before it is "disastrously overwhelmed" by it. 
However, science fiction does not only deal with abstract future technologies and possible developments of the human society. Science fiction draws from the past and the present. It points the dangers that were present at the time of author's life, sometimes these dangers still linger and perpetuate themselves during our lifetimes.

Education in science fiction was often shown as a means for the subjugation in future societies. It was a tool which works in tandem with doctrine and technological development. Ideas of eugenics and transhumanism often backed the dystopic societies in science fiction literature and film. In Aldous Huxley's "Brave New World", Isaac Asimov's "The Naked Sun", and Andrew Niccol's film "Gattaca" eugenics and technology work with education to form "ideal" societies. This is why the paper will first discuss the basics of eugenics and transhumansim and the link between these movements. The second part of the paper will discuss the role of education, transhumanism and eugenics in the dystopian societies which are depicted in the afore mentioned science fiction books and film.

\section{Eugenics, Transhumanism and the Link Between the Two}

Eugenic ideas have been discussed by philosophers, philosophers, writers and rulers throughout history. Its roots and its quest for a "fine, healthy race" can be found in the ancient civilizations of Sparta, Rome and Greece. However it is with the arrival of the Francis Galton in the $19^{\text {th }}$ century that eugenics gets it scope and aims. Galton defined eugenics as "thescience which deals with all influences that improve the inborn qualities of a race; also with those that develop them to the utmost advantage." (Galton, 1904, p. 1). Eugenics sometimes went beyond the theoretical borders. In the United States, eugenicists sterilized the mentally challenged persons, persons who suffered from epilepsy and other neurological disorders, and criminals. The shocking realization is that these practices persisted on the American soil up to the 1970s. Unfortunately, the eugenic theory and practices of the United States influenced the Nazi Germany. German eugenicists and Hitler in particular looked up to American eugenicists (such as Harry H. Laughlin) and their practices in Cold Spring Harbor, California. The main difference between the two countries is the number of victims. As it has been well documented, Nazis' eugenics program resulted in numerous victims - 400,000 sterilized and 70, 000 killed under euthanasia program Action T4.

Max More, a philosopher and a futurist, offered the following definition of transhumanism: "Transhumanism is a class of philosophies of life that seek the continuation and acceleration of the evolution of intelligent life beyond its currently human form and human limitations by means of science and technology, guided by life-promoting principles and values" (More, 1990). It promotes an interdisciplinary approach to understanding and evaluating the opportunities for elevating the human condition and the human organism, opened up by the advancement of technology. Transhumanists pay attention to both present technologies, such as biotechnology and the information technology, and anticipa- 
ted future technologies, such as molecular nanotechnology and artificial intelligence (Philosophy of transhumanism, retrieved September 2, 2014 from http://humanityplus.org/philosophy/).

A transhumanist sees the current state of the human in an evolutionary transition, on a transitory journey from ape to human to posthuman, and thus its philosophy is called transhumanism. The goal of transhumanism, then, is the posthuman. The posthuman is a future being - a person - who constructs itself out of various technologies. The posthuman, although a speculative projection into the future, will be very different from current humans. A transhumanist yearns to reach intellectual heights as far above any current human genius as humans are above other primates; to be resistant to disease and impervious to aging; to have unlimited youth and vigour; to exercise control over their own desires, moods, and mental states; to be able to avoid feeling tired, hateful, or irritated; to have an increased capacity for pleasure, love, artistic appreciation, and serenity; to experience novel states of consciousness that current human brains cannot access (Bishop, 2010, p. 701)

According to transhumanists one way to reach the posthuman state is through enhancement of evolution. But, their program targets only the selected population of the world which can have the funds to apply genetic engineering on their future generation. Transhumanists tend to disregard atrocities in the history of the eugenic movement. Instead, they are structurally related to the older American variant that preceded and contributed to German thinking. The first goal of this eugenics is "enhancing mankind" through the medical control of future generations, eliminating the "bad" and promoting a "good" person. Transhumnists' and bioethicists' promise of "enhancing evolution" is the same one that the eugenicists proposed in the 1920s: "The self-direction of human evolution". The ideas of the transhumanists and bioethicists correspond to those of English, American and Nazi Germany eugenicists. Bioethics, a branch of applied ethics, has been similarly focused on that eugenic promise to "help mankind toward a rational but cautious participation in the process of biological and cultural evolution” (Reich, 1993, p. 6, 7).

\section{Education, transhumanism and eugenics in Huxley's, Asimov's and Niccols' works}

Huxley used his work to show how the use of eugenics as a state tool can lead to a dystopian state, where individuals are created and moulded according to state needs. He shows us a dystopia that goes with, rather than against, the human grain. Indeed, it is animated by "progressive" aspirations of the eugenicists. Following those aspirations to their ultimate realization, Huxley enables the readers to recognize evils that are inextricably linked to the successful attainment of partial goods.

The plot of the novel is set in the distant future of 632 (AD 2540 in the Gregorian calendar). The world is unified in a single technocratic state, whose population is limited to no more than two billion people. In London Hatchery 
and condition centre the state practices an operation which they deem necessary "for the good of Society" (Huxley, 1932, p. 6). The procedure involves changes in the development of embryos (by reducing oxygen levels during growth of an embryos, "the lower the caste the shorter the oxygen" (Huxley, 1932, p. 12)). The embryos are classed and treated differently depending on the position they will hold in society. After the fertilization process "the fertilized ova went back to the incubators; where the Alphas and Betas remained until definitely bottled; while the Gammas, Deltas and Epsilons were brought out again, after only thirty-six hours, to undergo Bokanovsky's Process." (Huxley, 1932, p. 6) The process allows making multiple embryos from a single one, thus enabling faster "production line" constantly producing twins, a uniform line of men and women who will together carry the motto of the state "Community, Identity, Stability". During the development the embryos are conditioned to the environment in which the grown adult will be residing, and get immunized against diseases. In addition to the biological treatment, the subjects receive psychological treatment. Conditioning of involuntary reflex is used so as to evoke loathing of books and nature, because "a love of nature keeps no factories busy." (Huxley, 1932, p. 17) Through hypnopaedia - sleep teaching - the citizens are taught to love their position in society and they never question the whole automatized and dehumanized process of citizen production. In other words, this method bypasses the need for forceful subjugation of citizens and the state apparatus makes citizens who accept the system and ideology. The state creates a population of Gammas, Deltas and Epsilons whose task is to do manual labour and blindly obey the state and castes of Alphas and Betas who serve as leaders and represent the more intelligent layer of society. In order to keep them in check the people are trained to consume, to never be alone, and to have an addiction to Soma. Soma is a state produced drug which enables the citizenship of Huxley's "Brave New World", to have a religious experience within the state run "religious" organizations.. In other words, the state eliminates the individual's need for religion or other personal allegiances - the state becomes the sole focus of the citizens. Free sexual intercourse is encouraged and in the world state of "Brave New World" everyone belongs to everyone else, while emotional relationships are frowned upon. Free sexual intercourses provide a distraction to the population and enabled easier control, so the citizens give no trouble to their superiors.

When Huxley wrote "Brave New World" he warned about the future that may come if eugenics is applied on a massive scale. Even though this Brave New World doesn't suffer from famine, wars, diseases and overpopulation, it represents a gloomy prospect for humanity. Eugenic ideas threaten the liberty of human beings and enable the state to produce and manage the whole world population to its whim. The humanity becomes enslaved in perpetual substance abuse, cheap entertainment, and state managed eugenics. Even though it eliminates famine, war and disease, eugenics builds its ideal world on the elimination of "lower" humans, slavery and subjugation of the individual. Soon after the publication of Huxley's "Brave New World", an ominous political movement gained power in Germany: the Nazi movement started applying eugenic ideas on a massive scale. 
In "The Naked Sun" Elijah Baley is called to solve the case of murder on the planet Solaria. He is accompanied by a humanoid robot by the name of R. Daneel Oliwav, who had previously helped him in the novel "The Caves of Steel". Planet Solaria resembles Earth, but is more fertile, with lots of open space. It is a self-sustaining planet with 20,000 inhabitants, the number which is considered to be optimal for the Solarians. But Solarians have around two hundred million robots serving their needs which amounts to ten thousand robots per capita. Each Solarian owns his or her own estate, "they live completely apart and never see one another except under the most extraordinary circumstances." (Asimov, 1957, p. 32) The Solarians "view" each other using threedimensional images - holograms. Even married people live in this emotionally detached way. As Gladia, the wife of the killed Solarian Dr. Rickaine Delmarre, says, she "viewed" her husband "whenever necessary." (Asimov, 1957, p. 40) The marriages on Solaria are arranged and sexual encounters between husband and wife are scheduled, physical contact is avoided at all cost. This is dictated by their culture and upbringing. Couples are "matched" using "gene analysis" when they are young and even if the future spouses are not ready for the marriage they "grow accustomed to one another, and a little bit of seeing each day, once the initial queasiness is gone..." (Asimov, 1957, p. 105) The state forces its choice of a suitable mate upon the individuals and it is all done for the sake of the community. The citizens accept it because from an early age they are conditioned to accept the eugenic principles of Solarian society. Asimov shows that technology will lead to technocracy. Technology will become a prison with no bars: it is and will, as Winner (1977) sees it, "a source of domination that effectively rules all forms of modern thought and activity. Whether by an inherent property or by an incidental set of circumstances, technology looms as an oppressive force that poses a direct threat to human freedom "'(Winner, 1977, p. 3).

Another Spartan custom which appears on Solaria is the practice of eugenics. However, the Solarians have surpassed the methods used in Sparta. The method used is foetal engineering - the foetuses are inspected on a "farm" on which foetuses are selected and grown in a room with:

"perfectly controlled heat, perfectly controlled humidity, perfectly controlled asepsis. Those tanks, row on row, each contained its little creature floating in a watery fluid of precise composition, infused with a nutrient mixture of ideal proportions. Life and growth went on. Little things, some smaller than half his fist, curled on themselves, with bulging skulls and tiny budding limbs and vanishing tails" (Asimov, 1957, p. 95).

The number of grown foetuses is controlled so that the population is kept in check. Robots tend to the foetuses, but they "can't be trusted to judge the situation accurately when human life is involved..." they take "too much risk of overvaluing a life and saving one improperly" (Asimov, 1957, p. 95). Solarians value only healthy foetuses while the robots are thought of as "defective" because they value every human life. In this regard they are more humane than the cold and rational Solarians. Dr. Rickaine Delmarre predicted advancement in the practices of eugenics in Solaria. These practices resemble of negative eugenics depicted in Aldous Huxley's "Brave New World" and Dr. Delmarre's prediction finally eliminated the need for human contact. 
"...the time would come when unfertilized ova would be stored in banks at liquid-air temperatures and utilized for artificial insemination. In that way, eugenic principles could be truly applied and we could get rid of the last vestige of any need for seeing" (Asimov, 1957, p. 102).

According to Asimov space colonization may require future generations to apply the principles of negative eugenics - population control, ectogenesis, genetic manipulation and genetic analysis for the purpose of finding suitable mates. Technology will enable space colonizers to eliminate the need for human contact, they will live long and prosperous lives without the "hinderance" of human emotion or contact. This society would be a perfect techno-utopia, a new breed of emotionless, technologically dependent humans will spread to the far reaches of space. These humans will be quite different from the rest of humanity, Earthman, and will transcend the boundaries of the human body. They will become transhuman.

When the foetuses grow, the children grow up and get conditioned in the Solarian way of life. Foetal engineers oversee children and use robots as nursemaids. The only problem is robots' refusal to punish children. The scientist on Solaria tried to weaken the first law and implement a new first law: "discipline today for a better life tomorrow" (Asimov, 1957, p. 102). Robots' inability to punish the children can lead to the children's refusal to follow the rules required for the functioning of the Solarian society, therefore the punishing of the children is done by Solarians themselves. On the farm the children are taught to view each other from an early age and to avoid physical contact. "By viewing, they can walk together, talk together, race together, play together. Anything except physical contact" (Asimov, 1957, p. 103). As in "Brave New World", the children are trained from an early age, and later on become parts of the system and fully functioning members the society. Upbringing on Solaria can be compared to computer programming. The children are imprinted with a set of rules which they must follow to the letter but since every system has glitches they are monitored and reprogrammed to follow this specific line of command. Preservation of the system is paramount, personal wishes and aspirations are irrelevant, and the human's need for physical contact suppressed to the point of extinction.

Gattaca" (Niccol, 1997) is concerned with the kind of impact widespread use of this technology will have on an engineered individual's sense of selfidentity and on our identity as a species. The movie illustrates and shares Habermas' ideas on the impact of genetic modifications on the human condition, such as the expectations imposed by parental choices, the relationship to those who are not engineered, and human objectification. (Kirby and Gaither, 2005, p. 265). In "Gattaca", one sibling is unaltered and the other is altered. But in "Gattaca" the focus is on the struggle of a passionate unmodified human called Vincent to achieve a place amongst the astronauts in the Gattaca research center. The center is known for its exclusion of the "natural" or the "Invalid" humans i.e. humans who are not genetically altered. The name "Gattaca" consists of the four letters of DNA code - GTCA. Gattaca, in its stainless steel settings, 
dark-suit dress code, and drone like employees, suggests a genetically uniform, conformist world purified of flaws. This supports one of the arguments against genetic controls - a reduction in human diversity. "There is no gene for the human spirit' served as the film's tagline.

The movie foresees a future in which each individual's life span and ailments can be determined through DNA analyses. In fact, Gattaca's society has so much confidence in the predictive power of genomics that their culture revolves around these expectations. In Gattaca's world, no one is free to pursue a life of his or her own choosing. All people, modified and unmodified, suffer under the burden of expectations based on their genomes. Vincent, the protagonist, should have the opportunity to determine his own life's path. However, society expects that the only suitable career for an unmodified genome is janitorial. As a "faith birth," Vincent's genome is randomly determined and consists of genetic sequences that geneticists would have selected to leave out of a modified person. These sequences indicate a probability that Vincent will develop certain medical problems over the course of his life. However, in Gattaca's society genetic probability has become certainty, and people consider Vincent sick from the day he is born (Kirby and Gaither, 2005, p. 269). Vincent is a child conceived out of love but his DNA is riddled with "errors." As Vincent explains "From an early age I came to think of myself as others thought of me, chronically ill" (Niccol, 1997). His brother Anton is genetically altered and represents a "correction" of inadequacies in Vincent's makeup. As he gets older, however, Vincent decides to challenge these expectations. Vincent's desire to become an astronaut leads to this exchange with his parents:

"Marie: Be realistic, with a heart condition like yours.

Vincent: Mom, there's a chance there's nothing even wrong with my heart.

Antonio: One chance in a hundred.

Vincent: Well, I'll take it, alright?" (Niccol, 1997)

Instead of considering the possibility that he will not develop a heart problem, his parents assume that he is already sick. Instead of believing that everyone is free to find their own identity, Vincent's parents believe in the society's interpretation of his genome will determine his life's path (Kirby and Gaither, 2005, p. 270). They are satisfied to live in a society where an individual's life is dictated by his origins, not by his actions. The whole society of Gattaca shares ideas on development and heritage discussed and argued for by Plato, and later on Galton and his eugenic and transhumanistic followers.

Even though Vincent excels in astronomy and navigation, and possesses athletic build, he is denied admission to Gattaca. In this future society he is an "Invalid" and therefore must do menial jobs such as cleaning. The whole society of Gattaca is based on classism. The genetically engineered obtain better positions in society while the "Invalid" perform "blue collar" jobs. This is exactly what criticizes in his book "The Future of Human Nature" (2003). Habermas notes that: 
"By depriving the fusion of two sets of chromosomes its contingency, the intergenerational relations lose the naturalness which so far has been a part of the taken-for-granted background of our self-understanding as a species"'(Habermas, 2003, p. 72).

Habermas considers the relationship between parent and child the foundation of our moral system, our "species ethic," because it establishes separate generations as people of equal birth. This species ethic, the minimal understanding of ourselves as humans, presupposes that we are all individual authors of our own lives. We change this equality by asserting authority over another person's biological foundations of personal identity through genetic alteration. Habermas believes that once we start enhancing our genome we may find ourselves in a preliberal society where we distinguish between "real" humans and the not-quite humans in the way we used to distinguish between enfranchised humans and, say, slaves or indentured servants. The indentured servants in "Gattaca" are the "invalids" and the prosperity of the "Valids" rest on the subjugation of those who are seen as lower species than they are. Niccol shows clearly the danger of genetic engineering - society will move back to master slave relations.

\section{Conclusion}

The science fiction works discussed in the paper warns us of the dangers which may come if we do not take a careful leap into a technocratic future. All those "wondrous" advances come at a price. The price is the future of humanity as we know it - an even greater gap will appear among human beings, one which may not be so easily breached. But, science fiction is not only a theoretical doorway into the future. It tells us something about the society we currently live. We already put too much of our faith into machines. Most parents today would rather leave the upbringing of their children to another person, thus the leap from human pedagogue to a machine one would not be so strange. Also, parents lean more and more towards the idea of using genetic enhancements on their children as they see these "enhancements" as a gateway to a secure future.

However, over resilience on machines and the use of genetic enhancements might just be the trigger which will hurl us into technocratic visions of authors such as Huxley, Asimov and Niccol. Therefore, we must stay vigilant and learn from science fiction so that the mistakes from the past and omens from science fiction may not haunt us in our future.

\section{References}

1. Asimov, I. (1957). The Naked Sun. New York City: Doubleday

2. Bishop, J. (2010). Transhumanism, Metaphysics, and the Posthuman God. Journal of Medicine and Philosophy. 35, 700-720.

3. Galton, F. (1904). Eugenics: Its Definition, Scope, and Aims. The American Journal of Sociology. Volume X; Number 1 
4. Goble, N. (1972). Asimov Analyzed. Baltimore: Mirage.

5. Habermas, J. (2003). The Future of Human Nature. Cambridge: Polity Press.

6. Humanity Plus (2014). Philosophy of transhumanism, retrived October 10, 2014. from http://humanityplus.org/philosophy/

7. Kirbi, D. and Gaither, L. (2005). Genetic Coming of Age: Genomics, Enhancement, and Identity in Film. New Literary History. Vol. 36, No. 2. 263-282

8. More, M. (1990). Transhumanism - Towards a Futurist Philosophy. Retrieved September 2, 2014. from http://www.maxmore.com/transhum.htm

9. Niccole, A. (1997). Andrew Niccol (director \& writer), "Gattaca" (film), Sony Pictures Entertainment (SPE), (World-wide) 1997

10. Reich, W. T. (1993). How bioethics got its name. The Hastings Center Report (Special Supplement). 23:S1-16. 1993

11.Huxley, A. (1932) (reprinted 2006). Brave New World. New York: Harper Perennial.

12. Winner, L. (1978). Autonomous Technology-Technicsout-of-Control as a Theme in Political Thought. Cambridge(USA): The Massachusetts Institute of Technology

Мс Душан Спасић

\section{ОБРАЗОВАЮЕ, ТРАНСХУМАНИЗАМ И ЕУГЕНИКА У ДЕЛИМА НАУЧНЕ ФАНТАСТИКЕ ХАКСЛИЈА, АСИМОВА И НИКОЛА}

Сажетак: Кьижевна дела и филмови научне фантастике често се сматрају за пуку разоноду. Међутим, књижевна дела и филмови научне фантастике су критика пропагираних идеја из времена аутора као и критика могућих последица, које технолошки напредак може имати на друштво. Циљь овог рада је критички преглед теме образовања у „Врлом новом свету“ (1932) Олдоса Хакслија (Aldous Hихlеy), ,Голом суниу“ (1957) Исака Асимова (Isaас Asimov), и филма „Гатака“ (1997) Ендру Никола (Andrew Niccol). Образовање је махом сматрано средством за контролу друштва, а у случају горе наведених аутора оно је средство путем којег дистопијска друштва постижу потчињавање поданика. Стубови таквих образовних система су елиминација слободне мисли, превелико ослањање на технологију и образовање које је махом преплетено са еугеником и трансхуманизмом. Рад такође разматра основне идеје које леже иза еугенике и трансхуманизма као и везу између еугенике и трансхуманизма.

Кључне речи: научна фантастика, трансхуманизам, еугеника, дистопија, потчињавање.

Примљено: 2. 11. 2014. године.

Одобрено за штампу: 5. 12. 2015. године. 